\title{
USE OF MEDIA EDUCATION TECHNOLOGIES IN PRIMARY SCHOOL
}

Nowadays media education is seen as a separate or integrated subject that enables the proper and conscious use of media opportunities for educational purposes. With help of media education, people can better understand media culture, think critically, and be resistant to manipulation.

Among the problems that slow down the process of introducing media education in general secondary education institutions experts and teachers themselves underline the lack of regulation of the introduction of media education at the national legislative level, lack of technical means and textbooks. In order to make the introduction of media education in general secondary education institutions more active, trainings and educational seminars are held in Ukraine to train teachers of educational institutions. Another step is to add appropriate information and communication competence to the Concept of the New Ukrainian School.

The modern pupils are surrounded by media texts and various sources of information, technical means and devices. Therefore, it is important to be able to distinguish important and useful information from aggressive and manipulative. In order for the process of mastering media culture to be efficient and interesting, it is important to emphasize attention to the applied technologies of media education.

For primary school children, the main media channels are television, cinema (animation), and video content from the Internet. When a child watches TV or gadgets for a long time, he or she becomes overwhelmed with information that reduces concentration. Media classes for this age should be practical and shouldn't take long time. Among the forms are games, conversations, competitions.

The process of media education consists of various pedagogical techniques. Most of them are based on teacher-student communication, the interactive component prevails. Therefore, game methods are important, especially for primary school pupils, which help to provide primary media knowledge in an easy way.

Key words: media literacy, media education, media culture, critical thinking, primary school, junior schoolchildren, media educational process, teaching methods, technologies.

(статтю подано мовою орихіналу)

Modern pupils are at the epicentre of the informational flow, the influence of social networks and electronic media in general. They cannot always separate useful information from false and destructive information. Children don't have much life experience; they are more prone to imitation. Therefore, children should be taught to work properly with information. Media education should be taught so that they are able to perceive, analyse, filter information and think critically.

A media literate person has the ability to perceive, analyse and evaluate the received data, as well as create their own messages. This is what media literacy subjects, which are introduced in general secondary education institutions around the world, including in Ukraine, are focused on. In order to properly organize media education in educational institutions, it is necessary to be familiar with the basic concepts and know the main stages of media education school movement development.

The aim of the article is to consider the ways of using media educational technologies in primary school.

The basic national work, which summarizes the issues of media education and media literacy, is the textbook "Media Education and Media Literacy". It presents approaches to the main definitions, basic theories of media education, provides general information about different types of media and their impact on the audience. Also, V. Ivanov, M. Koropatnyk, K. Levkivsky, L. Naidenova, G. Onkovych, B. Potyatynnyk dealt with issues of media education in Ukraine.

Among foreign scientists D. Buckingham, L. Masterman, S. Sheibe and F. Rogou should be noted, as well as Russian researchers O. Baranov, O. Fedorov, I. Chelyshev, O. Sharikov.

Media education technologies are applied, but at the same time they help to integrate the study of subjects into a general educational process, as the main task of media education is the formation of general information skills, information culture, and ethics of media communication.

The specific of media education from a pedagogical standpoint is as follows:

- Media education arises as a pedagogical necessity when there is freedom of perception and change of the pedagogical vector.

- Teacher and pupil have equal access to information. The teacher doesn't teach, but helps to understand the world, offers to analyse the information obtained at different levels.

- Media education implies that the teacher must skilfully use modern means of education, including digital and multimedia.

- The pupil can be ahead of the teacher in the level of knowledge of the technical component of modern media. The teacher should use this in the learning process to increase its effectiveness [2, p. 9].

Values and stereotypes of modern primary school pupil are formed under the influence of the Internet, television, modern film production. Therefore, the student must be able to navigate independently in the flow of information in the media environment, to resist negative influences, and to assess truthfulness of information. In such 
conditions, the teacher's activity is significantly complicated. In addition to special training in multimedia technology sphere, he must actively apply pedagogical techniques related to the culture of using digital technologies, the Internet, social networks, etc. Also, part of the learning process is transferred to pupils and depends on their level of activity. During the lesson, teacher must simultaneously with the presentation of the new material control the use of digital teaching aids.

In order to carry out the media educational process qualitatively and successfully, teacher himself must clearly understand the main goal, discuss it with pupils, regularly analyse the objectives of lessons. At the present stage, when the flow of information is constantly growing, at the first place is the ability to separate true information from false information, and find methods of manipulation. The reaction to this manipulation can be quite different. Manipulation techniques especially affect children, because the level of their critical thinking is still relatively low, so one of the main tasks is the ability to analyse media messages, texts. During the analysis, attention should be paid to the author's position, key points and actors. Analysis is related to creative imagination, critical thinking, and the ability to interpret information. However, the analysis should be carried out only after mastering other creative skills, as younger pupils should be prepared to interpret and evaluate media texts.

The specifics of school media education are also related to the integration processes taking place in the media sphere. Therefore, both traditional experience and new approaches should be taken into account when developing the concept of education. The most popular media channels of modern children are television and the Internet. If we talk about children of primary school age, they are more influenced by television, because not everyone has computer capabilities. Interactive media capabilities are especially popular because they involve communication, participation in what is happening on the screen, and includes gaming capabilities.

The most popular among primary school pupils are multimedia tools. Such tools can be both a source of new information and assistance in learning, and a means of communication, a form of recreation. The popularity of multimedia is caused by the availability of both information and the Internet itself.

New Internet opportunities open great prospects for the development of media education. This allows teachers create virtual video libraries to which them can contribute literature sources, as well as video and audio files that are needed to organize media education classes. Also, due to the Internet, a system of distance learning is being developed, which provides opportunities for teachers raise the level of media education.

The latest technologies are of interest and play a significant role in media education, as they meet its main objectives. In particular, there is training in the correct reading of media texts. With help of computer technologies and the Internet, pupils have access to any text and can work with them. [5, p. 91].

The specificity of teaching media education in a general secondary education institution depends on another important factor - the age of students. Therefore, in our study we will consider the features of the organization of media education classes in primary school.

Children of primary school age have a reorganization of all mental processes. In particular, perception, attention, memory, imagination, thinking, speech. Children gradually acquire the qualities that are inherent to adults. Such changes are due to the fact that children are increasingly involved and included in new activities and the system of interpersonal relationships.

However, a child at this age is still characterized by significant activity, restlessness, instability of attention. If children spend most of their free time watching TV hyperactivity is developed, and the constant rapid change of shots and actions on the screen does not allow them to focus on what is shown on the screen [4, p. 231].

Especially the combination of opposite components of the restructuring of mental processes and the development of activity, instability of attention are noticeable for pupils of first and second grades, who have not yet fully switched from games and entertainment to learning.

At this age, digital media has already presented in a child's life. Therefore, even first graders pupils have already had media experience. For this age, the screen media - movies, TV content - are in priority. Among such content, children of primary school age choose fairy tales, science fiction movies, and cartoons. Therefore, teachers should engage the child in the world of cinema through these options.

However, contact with the media is not limited to watching television or movies for younger pupils. Many primary school pupils are already active Internet users. Kids like to watch videos on the social network You Tube, as well as play games. But not all games or videos are good and educational. They often contain scenes of cruelty or violence. Not all children respond in the same way to such content. Therefore, the child's psyche is injured.

Modern primary school pupils have problems with concentration, logical thinking, and presentation of a clear and consistent text. One of the reasons for this is the overload of information that children receive from the media. To develop motivation for the learning process, it is necessary to activate cognitive activity, expand the range of interests. And although the child of primary school age is still quite inquisitive, but a large amount of information contributes to rapid fatigue, loss of interest, the desire to participate in other activities. This should be taken into account during the organization of media education events.

Perception in early school age is closely connected to emotions. Often children pay attention to what is in the sphere of their interest. At perception of media text of any channel of communication children's consciousness needs to select the most interesting, necessary information, and also to interpret, process it. Due to bright colours and a constantly changing picture, it is difficult for a child to perceive the text as integrity. Therefore, a superficial 
perception is appeared. This should be taken into account when developing media educational tasks for primary school pupils.

Considering the fact that children from primary school are already well acquainted with media channels and their content, the development of media literacy is becoming increasingly important, starting from primary school age. It is caused by several factors:

1. Primary school age is a very important period of intellectual, physical and psycho-emotional development of the child.

2. The modern child has already had significant experience of contact with the media, especially with audiovisual.

3. Primary school pupils are faced with an ever-increasing flow of information, so they often have difficulty when they need to critically evaluate information on their own, to show creative individuality [5, p. 105].

Researcher L. Bazhenova names the following tasks that can be used as a basis for media education of primary school children. They are: development of perception, artistic activity, evaluation of screen media works, assimilation of knowledge about language and pictorial means of screen media products [1, p. 6].

The perception of primary school pupils is fragmentary, especially in the first and second grades, so pupils still have difficulties with watching large media texts. They cannot watch a show or a full-length cartoon till the end. Therefore, it is important to select individual fragments and analyze specific episodes in the classroom.

If we talk about the forms and methods that need to be used for media education in primary school, the researcher I. Chelysheva distinguishes the following: games, creative tasks based on media material, quizzes, competition programs, dialogues and conversations [6, p. 106].

Game activities in primary school are the main form of organizing media education lessons. It promotes the development of attention, memory, intelligence. The importance of game activities is caused by the fact that the child just came out of the environment, where the main element of education was a game. Therefore, children are simply involved into games of different nature: role-playing, moving, didactic. During the game, children simultaneously receive positive emotions, give energy and learn. Because children are active users of computer technologies, game process can be diversified with their help.

The role of the teacher is variable in game forms. He can only be an observer, and can be actively involved in the process. However, it is important to remember that every child should be able to express their thoughts freely, even if mistakes are made at the beginning. Manifestations of emotional support can be a smile, physical contact through a handshake or hugs. Attention to the child's creative abilities should be constant.

Primary school pupils are interested in performing creative tasks based on media materials. In particular, it can be the creation of a video, drawings for a cartoon, selection of musical accompaniment, composing dialogues of characters, imitation of television programs and more.

The above-mentioned game activity is closely connected with the holding of contests, competitions, quizzes. This form of organizing lessons promotes the development of leadership qualities in children, organizes teamwork, and provides opportunities for self-expression in collective creativity. The main thing is that there was a friendly atmosphere in the classroom during them, and the competitions caused a healthy excitement.

Dialogue forms and conversations help to reveal the child, provide opportunities to train expression of their own thoughts, form sentences and more.

The traditional form of work remains relevant - review and analysis of some parts from media texts. After watching, the genre and artistic specifics should be singled out, the advantages and disadvantages should be discussed, and the viewed video material should be reviewed. This form performs a number of tasks at once. It promotes the development of aesthetic abilities of the audience, critical thinking. At the same time, the collective discussion of the revised material involves dialogue and discussion, which also allows the development of critical thinking.

For primary school students, viewing and analyzing cartoons will be an effective method. Some researchers have given its own title to this direction - Cartoon-therapy. It can be passive when the child just watches cartoons and active when pupils create cartoons on their own [3, p. 126]. By watching the animation, the child has the opportunity to learn how perceive the audiovisual component. In the future, this will help to evaluate other texts critically. The cartoons that are offered for analysis should not exceed 20 minutes, have a high-quality image, be designed for a specific age, and the plot should be as simple and clear as possible.

Conclusions. The modern pupil is surrounded by media texts and various sources of information, technical means and devices. Therefore, it is important to be able to distinguish important and useful information from aggressive and manipulative. Acquirement of media culture would be effective and interesting, if the applied technologies will be implemented in media education.

For primary school children, the main media channels are television, cinema (animation), and video content from the Internet. When a child watches TV or gadgets for a long time, he is overloaded with information that reduces concentration. Media lessons for this age should be practical and short.

Thus, it is possible to reliably protect oneself from the negative impact of modern information and communication technologies only through the development of information culture and competence, which should be formed in the context of continuous media education. 
Bibliography:

1. Баженова Л. М. Медиаобразование школьника (1-4 классы). Москва : Изд-во художественного образования Российской Академии образования, 2004. 55 с.

2. Бондаренко Е. А. Технологии медиаобразования в современной школе. Наукові записки. Серія : Педагогіка. 2013. № 3. C. $8-13$.

3. Кисла Н. Мульт-терапія як засіб розвитку творчих здібностей дітей дошкільного віку. Практична медіаграмотність: міжнародний досвід та украӥнські перспективи : збірник статей П'ятої міжнародної науково-методичної конференції, 31 бер. 1 квіт. 2017 р. Київ : Центр вільної преси, Академія української преси, 2017. С. 125-130.

4. Нетреба М. М. Впровадження медіаосвіти у закладах загальної середньої освіти. Актуальні проблеми науки та освіти : збірник матеріалів XXI підсумкової науково-практичної конференції викладачів, 01 лют. 2019 р. Маріуполь : МДУ. С. 230-231.

5. Челышева И. В. Методика и технология медиаобразования в школе и вузе / под. ред. А. В. Федорова. Таганрог : Изд. центр Таганрог. гос. пед. ин-та. 2009. 320 с.

6. Федоров А. В. Медиаобразование: история и теория : учебное пособие. Москва : МОО “Информация для всех”, 2015. $450 \mathrm{c}$.

\section{References:}

1. Bazhenova L. M. Mediaobrazovanie shkolnika (1-4 klassyi) [Student's media education (grades 1-4).]. Moskva: Izd-vo hudozhestvennogo obrazovaniya Rossiyskoy Akademii obrazovaniya, 2004. 55 s. [in Russian]

2. Bondarenko E. A. Tehnologii mediaobrazovaniya v sovremennoy shkole. [Media education technologies in modern school] Naukovi zapysky. Seriia: Pedahohika. 2013. № 3. S. 8-13. [in Russian]

3. Kysla N. Mult-terapiia yak zasib rozvytku tvorchykh zdibnostei ditei doshkilnoho viku. [Cartoons-therapy as a means of developing the creative abilities of preschool children.] Praktychna mediahramotnist: mizhnarodnyi dosvid ta ukrainski perspektyvy: zbirnyk statei Piatoi mizhnarodnoi naukovo-metodychnoi konferentsii, 31 ber. 1 kvit. 2017 r. Kyiv: Tsentr vilnoi presy, Akademiia ukrainskoi presy, 2017. S. 125-130. [in Ukrainian]

4. Netreba M. M. Vprovadzhennia mediaosvity u zakladakh zahalnoi serednoi osvity [Introduction of media education in general secondary education institutions]. Aktualni problemy nauky ta osvity: zbirnyk materialiv XXI pidsumkovoi naukovo-praktychnoi konferentsii vykladachiv, 01 liut. 2019 r. Mariupol: MDU. S. 230-231. [in Ukrainian]

5. Chelyisheva I. V. Metodika i tehnologiya mediaobrazovaniya v shkole i vuze [Methods and technology of media education at school and university] / pod. red. A. V. Fedorova. Tahanroh : Yzd. tsentr Tahanroh. hos. ped. yn-ta. 2009. 320 s. [in Russian]

6. Fedorov A. V. Mediaobrazovanie: istoriya i teoriya: uchebn. posobie dlya vuzov [Media education: history and theory: a textbook for universities]. Moskva: MOO "Informatsiya dlya vseh", 2015. 450 s. [in Russian]

\section{Нетреба М. М., Хаджинова І. В. Використання медіаосвітніх технологій у початковій иколі}

Сьогодні в усьому світі медіаосвіта розглядається як окремий або інтегрований предмет, який надає змогу правильно та свідомо використовувати можливості медіа в освітніх иілях. Завдяки медіаосвіті можна краме розумітися на медіакультурі, критично мислити, бути стійким до маніпуляцій.

Серед проблем, які роблять повільним процес впровадження медіаосвіти в заклади загальної середньої освіти, експерти та самі вчителі називають відсутність регламентаиії впровадження медіаосвіти на законодавчому загальнодержавному рівні, нестачу технічних засобів і підручників. Щоб введення медіаосвіти в закладах загальної середньої освіти відбувалося активніше, в Україні проводяться тренінги, освітні семінари з підготовки викладачів закладів освіти. Ще одним кроком є додавання відповідної інформаційно-комунікаційної компетентності до Концепиії Нової української школи.

Сучасний школяр оточений медіатекстами та різними джерелами інформації, технічними засобами та приладами, тому він має вміти виокремлювати важливу та корисну інформацію від агресивної та маніпулятивної. Щоб процес оволодіння медіакультурою проходив плідно та иіккаво, важливо робити акиент на прикладних технологіях медіаосвіти.

Для дітей молодшого шкільного віку головними медіаканалами є телебачення, кіно (анімація), а також відеоконтент з інтернету. Коли дитина довго дивиться телевізор чи гаджети, в неї виникає перенавантаження інформацією, щзо знижує концентрацію уваги. Медіазаняття для цьього віку повинні мати практичне спрямування та бути не тривалими за часом. Серед форм переважають ігри, бесіди, конкурси.

Прочес медіаосвіти складається з різних педагогічних прийомів. Більшість із них побудовано на спілкуванні вчителя й учнів, тобто превалює інтерактивна складова частина, тому важливими, особливо для початкової школи, є ігрові методи, які допомагають у легкій формі надати первинні медіазнання.

Ключові слова: медіаграмотність, медіаосвіта, медіакультура, критичне мислення, початкова школа, молодші школярі, медіаосвітній процес, методи навчання, технології. 